\title{
Állandó mágneses szikrongép szabályozó körének vizsgálata Simulink-környezetben
}

\section{Control of a Permanent Magnet Synchronous Motor in Simulink}

\author{
Katona Mihály, ${ }^{1}$ Kiss Péter ${ }^{2}$ \\ ${ }^{1}$ Budapesti Müszaki és Gazdaságtudományi Egyetem. Budapest, Magyarország, katona.mihaly@edu.bme.hu \\ ${ }^{2}$ Budapesti Müszaki és Gazdaságtudományi Egyetem. Budapest, Magyarország, kiss.peter@vik.bme.hu
}

\begin{abstract}
Nowadays, before the era of modern Steer-by-wire steering systems, the most widely used steering technology is Electric Power Steering (EPS). This paper contains the developing of a Permanent Magnet Synchronous Motor (PMSM) control circuit for EPS systems in Matlab Simulink environment. The mathematical model of the Permanent Magnet Synchronous Motor was created via the four equations that represent the relation between the fluxes, voltages and currents in d-q reference frame and the motor torque equation. Mathematical transformations are required to generate the equivalent input values of the model from analog input waves. In this way, the embedded software is able to communicate with the motor through the analog input and output signals. The control model was also tested in a physically implemented system. The control software is executed on a dSpace AutoBox hardware. The output interface block creates the output phase voltages specified by the control module, and the input interface block allows the phase currents generated by the output voltage to be measured back.
\end{abstract}

Keywords: synchronous motor, motor control, electric power steering, hardware-in-the-loop.

\section{Összefoglalás}

Manapság, a modern Steer-by-wire kormányrendszerek korszakát megelőzően, a legszélesebb körben alkalmazott kormányzási technológia az elektromos kormányzás, vagyis az Electric Power Steering (EPS). Jelen publikáció ezen kormányzási technológia szabályozási körének vizsgálatát és az EPS-rendszerekben alkalmazott egyik motortípus, az állandó mágneses szinkron motor (PMSM) Matlab Simulink-környezetben megvalósuló matematikai modellezését tartalmazza. Az állandó mágneses szinkron motor matematikai modellje a négy d-q koordinátarendszer-beli egyenletet felhasználva került kialakításra, amelyek a fluxusok, feszültségek és áramok összefüggését reprezentálják. A kívánt bemeneti értékek létrehozásához további matematikai transzformációk szükségesek, hogy az analóg bemeneti jeleket a szoftver fel tudja dolgozni. Ilyen módon a beágyazott szoftver képes kommunikálni a motorral, annak analóg bemeneti és kimeneti jelein keresztül. A vezérlés modellje továbbá egy fizikailag megvalósított szabályozó körben is felhasználásra került. A szoftvert egy dSpace AutoBox hardver futtatja. A cél a termékfejlesztési folyamat költségének csökkentése a várható kimeneti paraméterek szimulálásával.

Kulcsszavak: szinkron motor, villamosmotor-szabályozás, elektromos kormányzás, hardware-in-the-loop. 


\section{Bevezetés}

A járművekben leggyakrabban alkalmazott motortípus az állandó mágneses szinkron motor. Kormányrendszerek esetén is kedvelt széles fordulatszám- és nyomatéktartománya miatt. A kormányrendszer fontos része a motorvezérlés, mert üzem közben egy jelentéktelennek tűnő esemény, mint például egy bukkanón való áthajtás, jelentős terhelést okozhat, amely tranziensként megjelenik a szabályozórendszerben. Ipari környezetben az ún. hardware-in-the-loop tesztet alkalmazzák a szoftver validálására. Ahhoz, hogy egy vállalat megőrizze piaci előnyét, egy termék fejlesztésének költségeit a lehető legkisebb mértékűre kell szorítania. A modern számítástechnika és a matematikai implementálás lehetőséget kínál arra, hogy a hajtáslánc működése a termék megvalósítása nélkül megközelíthető legyen. Ez jelentős költségektől szabadítja meg a céget, ezáltal elősegítve annak piaci versenyképességét. A modellezés célja az előre definiált kimeneti paraméterek közelítése, elsősorban a motor nyomatékának, hullámosságának szempontjából. A szabályozó áramkör ún. hardware-in-the-loop (HIL) tesztekkel vizsgálható. Ebben a lépésben a programkód egy már kialakított tesztrendszerbe épített vezérlő áramkör mikroprocesszor egységére kerül feltöltésre, ahol működését mérésekkel lehet ellenőrizni. Egy ilyen rendszer megvalósítását Y. Huangfu és W. Liu tanulmánya foglalta össze. [1] Eredményeik alátámasztják a konstrukció sikerét és a folyamat elméleti összefoglalásának szükségességét.

\section{Elektromos kormányrendszer}

Az 1. ábrán bemutatott EPS-rendszer mechanikus, elektromos és vezérlő alrendszereket tartalmaz. Az EPS-rendszer egyik fontos része a vezérlőegység, amely az érzékelők által mért jeleket fogadja. Az összegyűjtött adatok a jármű sebessége, a rotorszög és a nyomaték. Az elektromos vezérlőegység (ECU) vezérli a szervomotort a szükséges kiegészítő nyomaték biztosításához. Annak érdekében, hogy a vezető számára nyújtott kormányzási élmény növekedjen, ennek a szabályozásnak pontosnak és gyorsnak kell lennie.[2]

\section{Matematikai modell implementálása}

\subsection{Kereszt- és hosszirányú mennyiségek}

Az egyenletek felírásánál fontos meghatározni a megfelelő koordinátarendszert. Kézenfekvő döntés a rotor pólusfluxusával együtt forgó rendszert

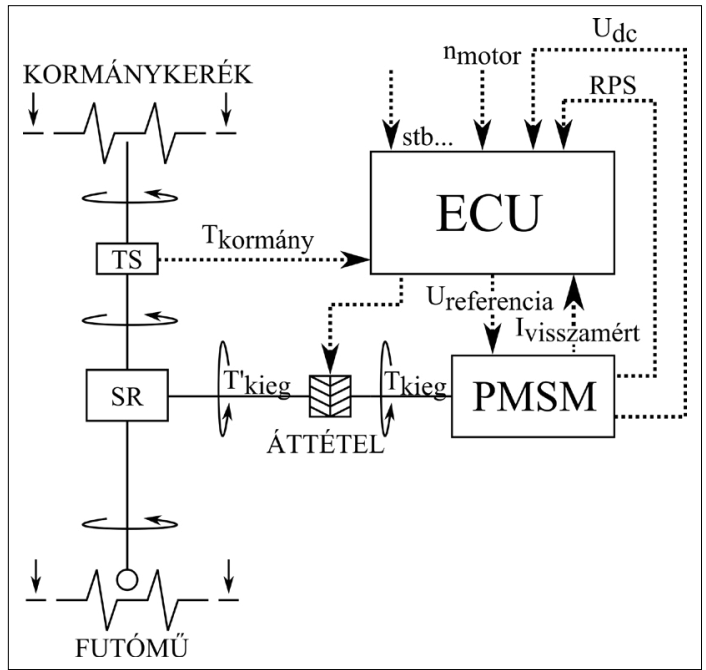

1.ábra. Elektromos kormányrendszer felépítése [3]

alkalmazni, ahol a hosszirányú komponens (d) a rotor pólusfluxusvektorához van rögzítve, amelyhez képest a keresztirány (q) $90^{\circ}$ villamos szöggel eltér. Ebben az esetben a villamos mennyiségek leírására nem szükséges trigonometrikus egyenleteket használni. Tehát a modellezés során a matematikai egyenletek más rendszerben értelmezettek, mint a HIL-teszt, és a kész termék esetén, ahol a programkód bemeneti paramétereit visszamért mennyiségek jellemzik, így szükséges a mért adatok transzformációja d-q koordinátarendszerbe.

Clarke-transzformáció esetén a visszamért háromfázisú mennyiségek a-b-c komponensei $\alpha-\beta-0$ referenciatartományba kerülnek az (1) és (2) egyenletek alapján. [4]

$$
\begin{aligned}
& {\left[\begin{array}{l}
f_{\alpha} \\
f_{\beta} \\
f_{0}
\end{array}\right]=\left[\begin{array}{ccc}
\frac{2}{3} & -\frac{1}{3} & -\frac{1}{3} \\
0 & \frac{1}{\sqrt{3}} & -\frac{1}{\sqrt{3}} \\
\frac{1}{3} & \frac{1}{3} & \frac{1}{3}
\end{array}\right] \cdot\left[\begin{array}{l}
f_{a} \\
f_{b} \\
f_{c}
\end{array}\right]} \\
& {\left[\begin{array}{l}
f_{a} \\
f_{b} \\
f_{c}
\end{array}\right]=\left[\begin{array}{ccc}
1 & 0 & 1 \\
-\frac{1}{2} & \frac{\sqrt{3}}{2} & 1 \\
-\frac{1}{2} & -\frac{\sqrt{3}}{2} & 1
\end{array}\right] \cdot\left[\begin{array}{l}
f_{\alpha} \\
f_{\beta} \\
f_{0}
\end{array}\right]}
\end{aligned}
$$

Park-transzformáció esetén az $\alpha-\beta-0$ referenciatartományú álló koordinátarendszer d-q-0 komponensekből álló együttforgó koordinátarendszerré kerül átalakításra. [5] 


$$
\begin{aligned}
& {\left[\begin{array}{l}
f_{d} \\
f_{q} \\
f_{0}
\end{array}\right]=\left[\begin{array}{ccc}
\cos \left(\varphi_{e}\right) & \sin \left(\varphi_{e}\right) & 0 \\
-\sin \left(\varphi_{e}\right) & \cos \left(\varphi_{e}\right) & 0 \\
0 & 0 & 1
\end{array}\right] \cdot\left[\begin{array}{l}
f_{\alpha} \\
f_{\beta} \\
f_{0}
\end{array}\right]} \\
& {\left[\begin{array}{l}
f_{\alpha} \\
f_{\beta} \\
f_{0}
\end{array}\right]=\left[\begin{array}{ccc}
\cos \left(\varphi_{e}\right) & -\sin \left(\varphi_{e}\right) & 0 \\
\sin \left(\varphi_{e}\right) & \cos \left(\varphi_{e}\right) & 0 \\
0 & 0 & 1
\end{array}\right] \cdot\left[\begin{array}{l}
f_{d} \\
f_{q} \\
f_{0}
\end{array}\right]}
\end{aligned}
$$

ahol a $\varphi_{\mathrm{e}}$ a rotorpozíció villamosszögben [rad].

\subsection{Villamos és mechanikai tulajdonságok matematikai közelítése}

A szinkrongép állandó mágnesei által ideális esetben előidézett mágneses mező szinuszos eloszlása leírható a pólusfluxusvektorral, vagyis elmondható, hogy a rotor fluxusa megegyezik a pólusfluxussal. A sztátor kapocsfeszültsége leírható a pólusfeszültség és a tekercselésen eső feszültség összegeként. [6]

$$
\begin{aligned}
& \boldsymbol{U}_{\boldsymbol{k}}=R \boldsymbol{i}+\boldsymbol{L} \frac{d \boldsymbol{i}}{d t}+j \omega_{e} \boldsymbol{L} \boldsymbol{i}+j \omega_{e} \boldsymbol{\Psi}_{\boldsymbol{p}} \\
& \omega_{e}=p \omega_{m}
\end{aligned}
$$

ahol,

$\omega_{e} \quad$ a rotor villamos szögsebessége [rad/s]

$\omega_{m}$ a rotor mechanikai szögsebessége [rad/s]

p póluspárok száma [1]

$\mathrm{Az} \mathrm{(5)} \mathrm{egyenlet} \mathrm{reális} \mathrm{része} \mathrm{adja} \mathrm{a} \mathrm{motor} \mathrm{hosszirá-}$ nyú (d), míg az imaginárius része a keresztirányú (q) komponenseket. Az említett egyenletekből érdemes az áramokat kifejezni, hiszen a szimuláció során a vezérlőjel a feszültség lesz, míg a visszacsatolást az áram biztosítja.

$$
\left[\begin{array}{c}
\frac{i_{q}}{d t} \\
\frac{i_{d}}{d t}
\end{array}\right]=\left[\begin{array}{cc}
-\frac{R}{L_{d}} & \frac{\omega_{e} L_{q}}{L_{d}} \\
-\frac{\omega_{e} L_{d}}{L_{q}} & -\frac{R}{L_{q}}
\end{array}\right] \cdot\left[\begin{array}{l}
i_{d} \\
i_{q}
\end{array}\right]+\left[\begin{array}{cc}
\frac{1}{L_{d}} & 0 \\
0 & \frac{1}{L_{q}}
\end{array}\right] \cdot\left[\begin{array}{l}
U_{d} \\
U_{q}
\end{array}\right]+\left[\begin{array}{c}
0 \\
-\frac{\omega_{e} \Psi_{p}}{L_{q}}
\end{array}\right]
$$

ahol,

$\mathrm{i}_{\mathrm{d}}, \mathrm{i}_{\mathrm{q}}$ motor állórészének árama [A]

$\mathrm{L}_{\mathrm{d}}, \mathrm{L}_{\mathrm{q}}$ állórész-tekercselés induktivitása [H]

$\mathrm{U}_{\mathrm{d}}, \mathrm{U}_{\mathrm{q}}$ kapocsfeszültség [V]

$\mathrm{R} \quad$ állórész-tekercselés ellenállása [ $\Omega]$

A nyomaték függ a pólusfluxus és az áramvektor kölcsönhatásától, amelyet a (8) egyenlet ír le.

$$
M=\frac{3}{2} p|\Psi \times \boldsymbol{i}|=\frac{3}{2} p\left(\Psi_{p} i_{q}+\left(L_{q}-L_{d}\right) i_{q} i_{d}\right)
$$

ahol,

M a motor villamosnyomatéka [Nm]

$\Psi_{\mathrm{p}}$ pólusfluxusvektor [Vs]

A fordulatszám egy rugó és egy tömeg párhuzamos kapcsolásának mechanikai egyenletével közelíthető.

$$
M(\varphi)=\Theta \ddot{\varphi}+D \dot{\varphi}+K \varphi
$$

ahol,

$\theta$ tehetetlenségi nyomaték $\left[\mathrm{kgm}^{2}\right]$

D csillapítási tényező [Nms]

Ktorziós tényező [Nm/rad]

$\mathrm{Az}$ ebben a fejezetben leírt egyenletek implementálásával és a megfelelő transzformációk felhasználásával a motormodell elkészíthető.

\section{Szinuszjellel vezérelt impulzusszé- lesség-moduláció}

„A szinuszjellel vezérelt impulzus szélesség moduláció (sPWM) az egyik legegyszerübb vivőjelen alapuló modulációs módszer. A vezérlés során egy magas frekvenciájú vivőjel kerül összehasonlításra egy szinusz alakú moduláló jellel [...]. A ciklusonkénti impulzusok számát a vivőfrekvencia és a moduláló jel frekvenciájának aránya határozza meg." [7]

Az inverter felépítéséből adódóan három hídágon, kettő-kettő tranzisztor 8 különböző kapcsolási állapotot határoz meg. A modellezés során kétszintű invertert valósítottam meg, ahol egy hídág vagy a pozitív, vagy a negatív sínre kapcsolható. Eltekintve a csillagpont eltolódásától és a veszteségektől, a motor fázisfeszültsége maximum az inverter egyenfeszültségének a fele lehet.

$$
U_{e}=\frac{U_{d c}}{2}
$$

ahol,

$\mathrm{U}_{\mathrm{dc}}$ inverter kapocsfeszültsége [V]

$\mathrm{U}_{\mathrm{e}} \quad$ sínfeszültség [V]

Háromfázisú szimmetrikus motor esetén minden egyes fázistekercs impedanciája azonos, $\left|\mathbf{Z}_{\mathbf{a}}\right|=\left|\mathbf{Z}_{\mathbf{b}}\right|=\left|\mathbf{Z}_{\mathbf{c}}\right|$, továbbá a fázisfeszültség-értékek a csillagponthoz vett előjeles összege is zérus $\mathrm{U}_{\mathrm{aY}}+\mathrm{U}_{\mathrm{bY}}+\mathrm{U}_{\mathrm{cY}}=0$. A csillagpont feszültsége $\mathrm{a}$ földhöz képest megegyezik a zérus sorrendű feszültséggel, amelyet a (11) egyenlet ír le, amenynyiben a két hídág pozitív sínre kapcsolódik. [8]

$$
U_{0}=\frac{U_{a}+U_{b}+U_{c}}{3}=\frac{U_{e}+U_{e}+\left(-U_{e}\right)}{3}
$$

ahol,

$\mathrm{U}_{0} \quad$ zérus sorrendü feszültség [V]

$\mathrm{U}_{\mathrm{a}}, \mathrm{U}_{\mathrm{b}}, \mathrm{U}_{\mathrm{c}} \quad$ fázisfeszültségek [V]

Ez alapján egy fázis maximális feszültsége:

$$
U_{f 0}=U_{a}+U_{0}=\frac{1}{3} U_{e}+U_{e}=\frac{4}{3} U_{e}
$$

Amennyiben a kapcsolási állapotokat álló koordinátarendszerben vizsgáljuk, ahol három tagból 
álló számsor reprezentálja a különböző kapcsolási állapotokat úgy, hogy 0 jelöli a hídág negatív, amíg 1 a pozitív sínre kapcsolt állapotát, akkor a vezérlés megkönnyítése miatt egy, a sokszög oldalaira belső érintő kört érdemes határfeszültségnek megszabni, vagyis a kivezérléstől eltekintünk. Jól látható, hogy a kiadott feszültségvektor abszolút értéke megegyezik a belső kör sugarával, amely a szektor magassága. Ez az egyenlő szárú háromszög magasságképletével számítható.

$$
r U_{e}=\frac{1}{2} a \cdot \cot \frac{\pi}{n}=\frac{1}{2} \cdot \cot \frac{\pi}{6}=\frac{\sqrt{3}}{2} U_{e}
$$

ahol,

r berajzolt kör sugara [v.e.]

a hatszög egy oldalának hossza [v.e.]

n s okszög csúcsainak száma [v.e.]

A modell felépítése során fontos meghatározni, hogy veszteségmentes esetben, kivezérlés nélkül a fázisfeszültség maximális értéke mekkora, amit a (14) egyenlet ír le.

$$
U_{f \mid \max }=U_{f 0} r=\frac{4}{3} \cdot \frac{\sqrt{3}}{2} \cdot \frac{1}{2} U_{d c}=\frac{1}{\sqrt{3}} U_{d c}
$$

A modellben az inverter kimeneti jelei $\pm \mathrm{U}_{\mathrm{f} \mid \max }$ között változnak. A három impulzusszélesség-modulációsillesztés közül - él-, középillesztett és adaptív - az első megvalósítása a legkézenfekvőbb. Kizárólag digitális környezetben futtatott szimuláció esetén az eredményekben számottevő különbség nem észlelhető. HIL-teszt esetén az árammérési módszertől függően érdemes adaptív illesztést alkalmazni. Élillesztett vezérlés a vivőjel-nagyfrekvenciás fürészfogjel (16-20kHz), amíg a moduláló jel térvektorokból számított.

$$
C=\left\{\begin{array}{l}
1, \text { ha } J_{m} \leq J_{v} \\
0, \text { ha } J_{m}>J_{v}
\end{array}, \text { ahol } J_{m}, J_{v} \in[0,1]\right.
$$

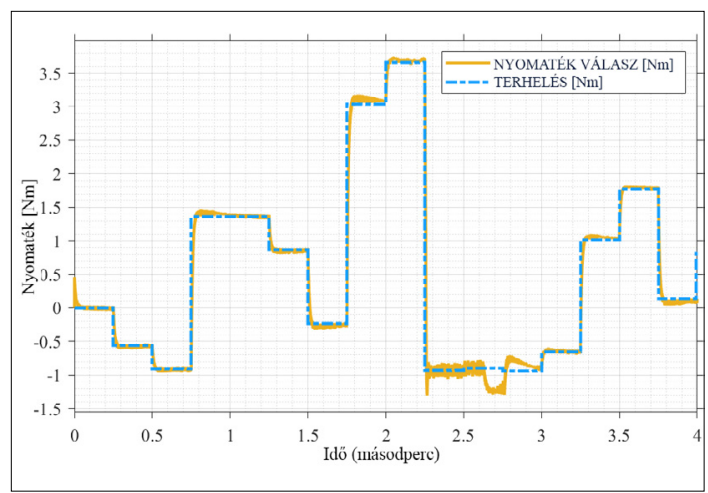

2. ábra. A rendszer nyomatékválasza ahol,

C inverter hídágainak vezérlőjele [v.e.]

Jm moduláló jel [v.e.]

$\mathrm{J}_{\mathrm{v}}$ vivőjel [v.e.]

A vezérlőjel kimeneti frekvenciája és amplitúdója a vivőjel frekvenciájától és amplitúdójától függ, közöttük lineáris kapcsolat áll fenn.

A szabályozó kör egyszerű, háromszintű topológiával kialakított, sorba kapcsolt sebesség-, nyomaték- és áramerősség-szabályozóval. Ezek PI-típusú szabályozók, amelyek Finn Haugen által kifejlesztett Good Gain-módszerrel hangoltak. [9]

\section{Eredmények és következtetések}

A 2. ábra mutatja a szabályozórendszer nyomatékválaszát a szimulált terhelésre. Ez utóbbi a kormányzásból eredő nyomaték, az úthibák és a kormányrendszer mechanikai veszteségének kombinációja. Az ábra azt mutatja, hogy a bemutatott szabályozó kör a várakozásoknak megfelelően működik, mert a nyomatékreakció gyors és pontos. Ezenfelül ez az eredmény alátámasztja, hogy a validálási folyamat megkezdhető, mivel a HIL-rendszer mechanikai veszteségei ismertek, szimulálhatók. A 3. ábra a differenciális nyomatékot mutatja, amely csillapítás nélkül érzékelhető a vezető számára. A magasabb tüskék értelmezhetők úgy, mint amikor egy jármű egy vasúti átjárót keresztez, és az alacsonyabbak adódhatnak például az úthibákból vagy a kormányzásból. A fejlesztési folyamat egyik célja a kiugró értékek csökkentése a vezetési élmény fokozása érdekében.

Ahogyan az eredményekből kiderül, a matematikai modell Simulink-környezetben történő megvalósítása hatékony módszer a kormányrendszer viselkedésének szimulálására, különös tekintettel a szabályozórendszerre.

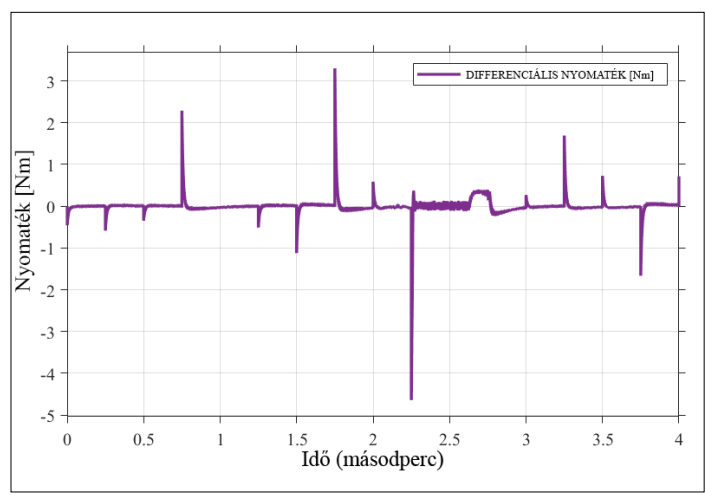

3. ábra. A rendszer differenciális nyomatéka 


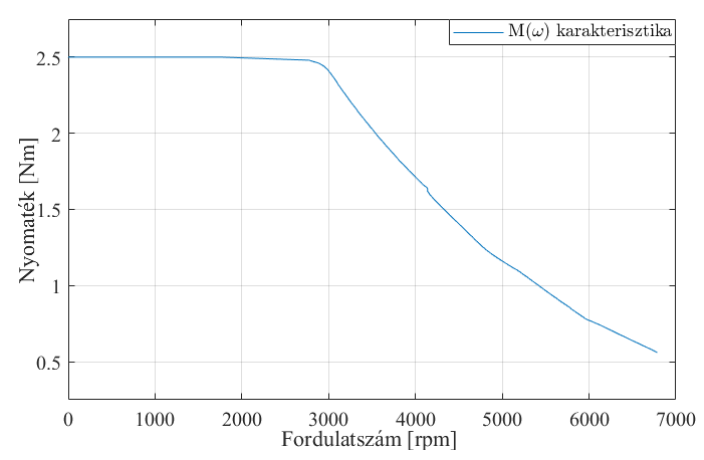

4. ábra. $T(\omega)$ karakterisztika

Továbbá ipari gyakorlatban elterjedt megoldás, hogy a motor tengelye és a hajtott tengely közé fogaskerék-áttétel kerül. Ez azon probléma kiküszöbölését hivatott megoldani, ha a motor nyomatéka nem elegendő. Ebben az esetben a motor fordulatszámának növelésével és az áttétel megválasztásával a hajtott oldali nyomaték növelhető. A motor fordulatszáma állandó teljesítmény mellett növelhető mezőgyengítéses üzem alkalmazásával. Ekkor a motornyomaték fordulatszám-karakterisztikája szimulálható. Az eredmény a 4. ábrán látható. Az említett karakterisztikából következtetni lehet a szükséges áttételre vagy fordítottan, adott áttétel mellett a megválasztott motor alkalmazhatóságára, esetlegesen a tervezési paraméterek finomítására.

\section{Köszönetnyilvánítás}

Köszönöm Handler Árpádnak és Dr. Vajsz Tibornak a hajtásszabályozások terén nyújtott segítséget.

$\mathrm{Az}$ ebben a cikkben közölt és a BME-n végzett kutatást az NRDI Alap támogatta az Innovációs és Technológiai Minisztérium égisze alatt az NRDI Iroda által kiadott megerősítő okirat alapján.

\section{Szakirodalomi hivatkozások}

[1] Huangfu Y., Liu W.: Rapid Development Controller Design for PMSM Based on Hardware-in-the-loop. $5^{\text {th }}$ IEEE Conference on Industrial Electronics and Applications, Taichung, 2010. 1963-1966. https://doi.org/10.1109/ICIEA.2010.5515537

[2] Hao C., Yali Y., Ruoping Z.: Study on Electric Power Steering System Based on Adams, Shanghai University of Engineering Science. Procedia Engineering, 15. (2011) 474-478.

https://doi.org/10.1016/j.proeng.2011.08.090

[3] Shaoyun Z., Yi W.: Study of Electric Power Steering System. International Conference on Computer Science and Intelligent Communication, 2015. https://doi.org/10.2991/csic-15.2015.77

[4] [Chakraborty A. K., Bhattachaya B.: Determination of $\alpha, \beta$ and $\gamma$-Components of a Switching State without Clarke Transformation. $2^{\text {nd }}$ International Conference on Control, Instrumentation, Energy \& Communication (CIEC) 2016, 260-264. https://doi.org/10.1109/CIEC.2016.7513764

[5] Pillay P., \& Krishnan R.: Modeling of Permanent Magnet Motor Drives. IEEE Transactions on Indus-trial Electronics, 35/4. (1988) 537-541. https://doi.org/10.1109/41.9176

[6] Vajsz T., Rácz Gy., Számel L.: Novel Modified dtcsvm Method with Better Overload-Capability for Permanent Magnet Synchronous Motor Servo Drives. Periodica Polytechnica, Electrical Engineering and Computer Science, 61. (2017) 253-263. https://doi.org/10.3311/PPee.10428

[7] Vijayakumar K.: Application of Sinusoidal Pulse Width Modulation Based Matrix Converter as Revolutionized Power Electronic Converter. Lecture Notes in Electrical Engineering, 326. 2014.

[8] Schmidt I., Veszprémi K.: Hajtásszabályozások. https://vet.bme.hu/?q=kutatas/tamop/anyagok

[9] Haugen F.: The Good Gain Method for Simple Experimental Tuning of PI Controllers. Modeling, Identification and Control, 33/4. (2012) 141-152.

[10] Kuslits M.: Állandómágneses szinkrongépek modellalapú irányításfejlesztése. Publio Kiadó Kft. 2016. 